A gente tem de sair do

sertão! mas só se sai do

sertão é tomando conta dele a dentro 


\section{Demorada descoberta de Guimarães Rosa}

José Mindlin | Academia Brasileira de Letras

Fala-se tanto, este ano, em Guimarães Rosa que fica difícil apresentar um texto que se diferencie claramente do que se tem dito ou publicado. Sinto essa dificuldade apesar de ser um "rosiano" entusiasta. Achei que poderia ser interessante, em vez de comentar sua obra que é genial, fazer um depoimento sobre como o conheci, o que foi curioso, especialmente em relação à leitura.

Encontrei-o em Paris, em 1946, ano da Conferência da Paz em que Rosa tomava parte como membro da delegação brasileira. Eu tinha ido à Europa para formar o estoque de uma livraria de livros raros que um amigo bibliófilo e eu tínhamos resolvido criar. Meu irmão Henrique e minha cunhada Vera Bocayuva eram amigos de Rosa, assim como Luís Camillo de Oliveira Netto, meu grande amigo, e os três me tinham recomendado para procurá-lo em Paris. Fiz isso logo e se estabeleceu rapidamente uma simpatia mútua.

Como os trabalhos da Conferência de Paz só começavam depois da hora do almoço, Rosa e eu passamos a nos encontrar pela manhã, isso acontecendo várias vezes durante o mês em que permaneci em Paris. Encontrávamo-nos e dávamos um giro pelas livrarias, sempre batendo um papo agradável. Era um homem elegante, com senso de humor, uma espécie de contador de casos, o que facilitou a conversa, mas essa não tinha objetivos 
específicos: era aquilo que se chama um bom papo. Acontece que, durante todas as conversas, Rosa não me deu a mínima indicação de que fosse escritor e, aliás, ele ainda não era famoso, tendo, inclusive, perdido anos antes um prêmio de literatura para Luís Jardim, autor de Maria Perigosa. Isso era muito pouco para que ele entrasse no meu espírito como escritor, eu que reverenciava os autores de obras literárias.

Justamente nessa época, Sagarana estava sendo publicado e eu, quando voltei ao Brasil, achei que não deveria ser nada de muito especial, pois o jeito de Rosa nos nossos encontros tinha um tom descompromissado. O livro estava tendo sucesso, mas eu tinha e ainda tenho prevenção em relação a livros de imediato sucesso, os chamados best-sellers, e preferia esperar um tempo para que esse sucesso se decantasse. Geralmente esperava um ou dois anos, mas dessa vez passou muito mais tempo, pois os anos 40 e iniciais da década de 50 foram muito férteis em outras leituras. Acontece que, em 1956, um amigo cujas opiniões eu respeitava, me perguntou se eu já tinha lido Guimarães Rosa e eu, na maior inocência, disse que não e indaguei a razão da pergunta. A resposta foi altamente taxativa: "Você não pode deixar de ler suas obras, pois o homem é genial!" Segui o conselho, assim mesmo, cheio de dúvidas, mas o resultado não podia ser outro: fiquei no maior entusiasmo, que continua até hoje.

Li primeiro Sagarana, depois Corpo de baile e, finalmente, o Grande sertâo: veredas, que depois reli periodicamente. O entusiasmo continua muito vivo, e para mim Guimarães Rosa passou a ser o maior escritor do século XX, como Machado de Assis foi do século XIX. Dizer que foram os maiores é um elogio muito significativo, pois o Brasil, em matéria de bons escritores, foi muito fértil - enumerá-los levaria muito longe este depoimento. Cheguei a gravar com Antonio Candido e Davi Arrigucci, professor de Literatura da USP, um CD em que lemos, alternadamente, sete episódios do Grande sertão (escolhidos por Davi que conhecia o Grande sertão de cor) e que davam idéia da trama da obra. Essa leitura me revelou a excepcional musicalidade da linguagem de Rosa. Seu texto lido em voz alta ganha relevo ainda maior do que na simples leitura.

As comemorações do cinqüentenário de Corpo de baile e Grande sertão são amplamente justificadas e eu gostaria de poder assistir - mas isso não depende de mim - às comemorações do centenário, certamente ainda mais entusiásticas, pois para mim é difícil imaginar que nos próximos 50 anos surja outro escritor tão genial quanto o nosso Guimarães Rosa. 